by which the cell as a whole reacts to the presence of the drug in an almost predictable way. The same general comments might be made about the 'spontaneous mutations' in the absence of division, to histidine-independence of a bacterial strain recently studied by Ryan.

In spite of some alarm, physico-chemical mechanisms of cell adjustment need not be in any conflict at all with valid principles of genetics. But it is a misapplication of the latter when they are used to exclude all mechanisms except selection of random mutants or of favourable gene combinations. Random mutations to drug resistance may indeed be shown by the relatively rare examples where the Lederberg technique of replica plating has given positive results. Nature, however, presents us with a vast hierarchy of systems : sub-atomic units (in a vast and confusing array), atoms and molecules, micelles, chromosomes, nuclei, cells, colonies, tissues, individuals and communities of individuals. Nobody can suppose that all phenomena have their origin at any one particular level.

In the organisms studied by classical genetics, individuals develop from fertilized germ cells, and, not surprisingly, show characteristics largely inherent in those cells. In micro-organisms which multiply by binary fission, the new individual does not develop from a much smaller germ cell but is formed by the approximate halving of an existing one, and, no more surprisingly, shows the characteristics of this. The manifestation of the effects of genes has long been recognized to be profoundly affected by their environment, so that the subsequent growth of the divided daughter cells is largely governed by the total organization. This explains-and more specific physico-chemical illustrations can be given-why such characters as drug resistance due to enzymatic reorganization can persist through many divisions. But to call the phenomenon or its interpretation Lamarckian is a plain misuse of language.

The disentangling of the complicated and fasginating relationships met with in this field will demand close co-operation of the physical and biological sciences, which brings me back to the keynote of this address. To the highly ingenious models of structure must be added equally illuminating models of function. Whatever the answer may be to the controversial problems of to-day, that is what the future in one way or another will surely bring forth.

\title{
OBITUARIES
}

Prof. Winifred Cullis, C.B.E.

By the death on November 13 of Prof. Winifred Cullis the world has lost not only a fine scientist but also an outstanding personality.

Winifred Clara Cullis was born in Gloucester on June 2, 1875. King Edward VI's High School for Girls, Birmingham, and Newnham College, Cambridge, laid the foundation of her abiding interest in science and began many life-long friendships. In 1901 she was appointed demonstrator in physiology at the London (Royal Free Hospital) School of Medicine for Women; later she became lecturer, reader and head of the Department, and finally professor of physiology in the University of London. She retired during the Second World War.

From the beginning, research was Prof. Cullis's great interest, and her name will always be associated with two outstanding pieces of work, one on the mechanism of the secretion of urine and the other on the perfused isolated heart of rabbit. Her experimental technique was precise and careful, and it was a joy to see the delicacy and sureness with which she would snip sufficient of the auriculo-ventricular bundle in the beating heart in order to demonstrate the effects of partial heart block. In later years lectures at home and abroad made continued research work more difficult; but periodically she would give herself a 'holiday' and with one or more colleagues settle down for several weeks investigating some interesting problem. She gave unstintingly of her knowledge and wide experience to her departmental colleagues but always insisted that publications should be in their own names, and any appreciation of their work gave her great pleasure.

No one who knew her could be other than filled with admiration for the absolute integrity and shining honesty which characterized her scientific outlook and the public work which later claimed so much of her time. For self-seeking, pomposity or hidden motives she had no use, and nothing was more direct than her own approach to a problem.

This directness, together with her gaiety and wit, made her lectures and speeches unforgettable. She had a store of appropriate stories-often against herself-and it was seldom that a specch of hers was not punctuated by laughter.

She herself realized how valuable were her special gifts as a speaker, and she gladly spoke for any cause she had at heart, particularly where she felt she could assist in securing for professional women equal opportunity and status with men. Her great charm was to a large extent due to her intense interest in and understanding of her fellow men and women. 'This and her generous appreciation of the other person's point of view, even when she disagreed, was particularly valuable in international contacts. In her work for the British Federation of University Women and for the International Federation of University Women, in each of which organizations she held the presidency for a number of years, she combined her interest in the advancement of women and her belief in the great value of international understanding and good will

Of the many honours and marks of appreciation that came her way, few gave Prof. Cullis greater pleasure than the decision of the British-American Associates to name one of their lecture fellowships after her.

She felt strongly that physiology should be taught in the schools and gave a series of most successful talks in the B.B.C. Schools Programme. She wrote two excellent books on the subject for use in schools. "Your Body and the Way it Works", published in 1949 , is a very clever blending of her text with pictures by Ian T. Morison. Included is a section on growth, reproduction and heredity which is an aspect of human biology normally omitted from elementary books. 
Few women could have had so many friends. She collected them from a world-wide circle. Her memory for them was amazing, and she would call to mind details about people she had not met for years and with whom she could have had the briefest conversation.

The loss of Winifred Cullis leaves a void in the lives of those who knew her, not only because she was a unique personality but also because of the deep affection she inspired.

M. BOND

\section{Dr. A. L. Clark}

IT was with a sense of genuine sorrow that the many friends of Dr. Arthur Lewis Clark learned of his death on September 20 at Kingston, Ontario, at the age of eighty-three.

Dean of the Faculty of Applied Science at Queen's University, Ontario, for twenty-four years from 1919, an outstanding physicist in research, Dr. Clark had retired in 1943, but continued to lead a full and active life until a short illness before his death. Dr. Clark was born on February 19, 1873, at Worcester, Mass., where he was educated, going to the Polytechnic Institute, where he obtained his B.Sc. degree. After doing his graduate work and some teaching, he went to Queen's, University in 1906 as head of the Physics Department.

Dr. Clark's scientific interest was in thermodynamics and he carried out considerable research in this field. In 1916 he was appointed chairman of the University Scientific Research Committee. His recommendations with regard to the support of research at that time were far-reaching and estab. lished standards worthy of acceptance by any university to-day. In $1919 \mathrm{Dr}$. Clark was appointed dean of the Faculty of Applied Science, a post which he held until his retirement in 1943.

Retirement did not mean idleness to Dr. Clark, for one of the first tasks he set his hand to was writing his own now famous Queen's document, his book "The First Fifty Years", a history of the Science Faculty of Queen's from 1893 until 1943. 'The book filled a blank in the University records and has been enthusiastically received by graduates of all faculties.

During these twenty-four years there was war and depression, bringing great stress and strain to the University. Nevertheless, under Dean Clark's wise and efficient guidance, the standards of work in the various branches of engineering were more than maintained and the School of Applied Science grew to maturity. Dean Clark's firmness, tempered with patience and sympathy, won the esteem of staff, graduates and students alike.

In compiling the above note, I am indebted to Mr. David G. Dewar for information from his book, "Queen's Profiles", published by the office of Endow. ment and Public Relations, Queen's University.

H. G. CONN

\section{NEWS and VIEWS}

International Meteorological Organization Prize : Dr. H. T. Hesselberg

Dr. Hans Theodor Hesselberg, formerly director of the Norwegian Meteorological Institute and president of the International Meteorological Organization, has been awarded the International Meteorological Organization Prize. This Prize was created by the World Meteorological Organization to perpetuate the memory of the non-governmental international organization which that specialized agency of the United Nations has succeeded. It is to be presented once a year in lecognition of scientific contributions to meteorology and work for international meteorological organizations. Dr. Hesselberg, who has received the first award, was born at Lierne in Norway in 1885, and has devoted himself from 1912 onwards to meteorological and hydrological research. As scientific assistant to Dr. Bjerknes, he participated in research in the fields of dynamic meteorology and hydrology. He was director of the Norwegian Meteorological Institute during 1915-55. During these forty years he was mainly concerned with the organization of the Meteorological Service of Norway and international co-operation. From 1919, he took an active part in the work of the International Meteorological Organization, of which he was president during 1935-46. Dr. Hesselberg was a member of the executive committee of the World Meteorological Organization during 1951-55.

Mathematics in the University College of North Staffordshire :

Prof. D. S. Jones, M.B.E.

Mr. Douglas Jones, who has been appointed to the chair of mathematics in the University College of North Staffordshire in succession to Prof. I. N.
Sneddon (see Nature, 177, 1109 ; 1956), was educated at Wolverhampton Grammar School, and went up to Corpus Christi College, Oxford, with an open scholarship in 1940. Soon afterwards, however, he joined the R.A.F., becoming attached to night fighters as a signals radar officer. In 1942 he was put in charge of a special research unit, and for his work in this capacity was mentioned in dispatches and later made M.B.E. In 1945 he returned to Oxford, where he took first-class honours in mathematics two years later. Then he went with a Commonwealth Fund. fellowship to the Massachusetts Institute of Technology, where he started his researches on wave diffraction theory. This has continued to be his major research interest; but the power and complexity of the mathematical methods he has brought to bear on it have never been allowed to obscure in Jones's mind, nurtured alongside the pressing needs of war-time radar, the many practical applications of the results of his calculations. In 1948 he returned to England as an assistant lecturer in the Mathematics Department in the University of Manchester, where he was promoted to lecturer in 1951 and to senior lecturer in 1955. He has held the responsible position of tutor to the Faculty of Science since 1954, and while on leave of absence for six months in 1955 was a visiting research professor at the Institute of Mathematical Sciences, New York University. His most recent interest is a fundamental study of methods for calculating short-wave scattering.

\section{British Cotton Industry Research Association :} Dr. G. F. Davidson

Dr. G. F. Davidson, of the British Cotton Industry Research Association, head of the Chemistry Depart. ment at the Shirley Institute, Manchester, is resigning 